Article

\title{
Inhibitory Effects of Cycloheterophyllin on Melanin Synthesis
}

\author{
Joong-Hyun Shim (1)
}

check for

updates

Citation: Shim, J.-H. Inhibitory Effects of Cycloheterophyllin on Melanin Synthesis. Molecules 2021, 26, 2526. https://doi.org/10.3390/ molecules26092526

Academic Editors: Nadine Martinet and Melita Vidakovic

Received: 25 March 2021

Accepted: 21 April 2021

Published: 26 April 2021

Publisher's Note: MDPI stays neutral with regard to jurisdictional claims in published maps and institutional affiliations.

Copyright: (C) 2021 by the author. Licensee MDPI, Basel, Switzerland. This article is an open access article distributed under the terms and conditions of the Creative Commons Attribution (CC BY) license (https:/ / creativecommons.org/licenses/by/ $4.0 /)$.
Department of Cosmetic Science, Semyung University, Science \& Engineering Bldg/Room 313, Chungbuk 390-711, Korea; jhshim@semyung.ac.kr; Tel.: +82-43-6491615; Fax: +82-43-649-1730

\begin{abstract}
This study was performed to clarify the inhibitory effects of cycloheterophyllin on melanin synthesis. In order to elucidate the inhibitory effects of cycloheterophyllin on the B16F10 cell line, cell viability, messenger ribonucleic acid (mRNA) expressions, tyrosinase activity assay, and melanin production assay were measured. The effects of cycloheterophyllin on tyrosinase-related protein 1 (TYRP1)/TYRP2/tyrosinase (TYR)/microphthalmia-associated transcription factor (MITF) mRNA expressions and melanin content were determined. Quantitative real-time RT-PCR showed that cycloheterophyllin decreased the mRNA expression level of TYRP1/TYRP2/TYR/MITF genes and melanin production contents than $\alpha$-MSH-treated B16F10 cells. The tyrosinase activity assay revealed that cycloheterophyllin decreased the melanin production in the B16F10 cells. These data show that cycloheterophyllin increases the whitening effects in the B16F10 cells; thus, cycloheterophyllin is a potent ingredient for skin whitening. Thus, further research on the mechanism of action of cycloheterophyllin for the development of functional materials should be investigated.
\end{abstract}

Keywords: cycloheterophyllin; melanin; tyrosinase; microphthalmia-associated transcription factor

\section{Introduction}

The color of the skin is determined by hemoglobin in the blood, melanin pigment in the epidermal layer, and $\beta$-carotene in the subcutaneous tissue. Among them, the color of the skin is mainly determined by the amount and distribution of the melanin pigment [1]. Melanin is a pigment synthesized from the melanosome in the melanocyte that is present in the basal layer. It absorbs or scatters ultraviolet (UV) rays and has a beneficial function to suppress damage to the skin cells or skin tissues. However, excessive accumulation of melanin may cause spots, freckles, and pigmentation. It is known to cause hyperpigmentation [2,3].

Melanin pigment is a representative irritant that causes exogenous aging. It is produced by the melanogenesis of melanocytes that have been exposed to UV rays, and has a beneficial function of protecting the skin from UV rays by darkening the skin color. The melanin pigment consists of eumelanin (black) and pheomelanin (red brown) [4,5]. Melanin is produced by using L-tyrosine, a type of amino acid, as a substrate, and through L-DOPA (3,4-dihydroxyphenylalanine) and further oxidized to DOPA-quinone by the main enzymes tyrosinase (TYR), tyrosinase related protein-1 (TYRP1), and TYRP2. The DOPAquione is further oxidized to red-yellow pheomelanin in the presence of sulfhydryl groups. The DOPA-quinone also decarboxylated, oxidized, and catalyzed into eumelanin when sulfhydryl groups are depleted [4,5]. Tyrosianse enzyme is the key enzyme responsible for the production of melanin, and it is known that licorice extract, Japanese oak extract, arbutin, and kojic acid, which are representative whitening materials, inhibit the activity of tyrosinase enzyme [6,7]. In particular, arbutin plays a role in inhibiting the activity of tyrosinase by reacting competitively with L-tyrosine, which is a raw material for melanin, and kojic acid bound to the active site of the tyrosinase by $\mathrm{Cu}^{2+}$. Kojic acid and arbutin are known to have strong whitening effects, but side effects of safety issues such as skin irritation have been reported [8,9]. Many studies are being conducted to discover new effective materials such as the development of natural-derived functional materials [8,9]. 
Cycloheterophyllin $\left(\mathrm{C}_{30} \mathrm{H}_{30} \mathrm{O}_{7}\right)$, a type of prenylflavone, is abundantly contained in Artocarpus heterophyllus, and has been reported to have pharmacological and biological functions including anti-inflammatory, anti-platelet activity, and antioxidant efficacy [10-13]. In addition, it has been reported that it has antioxidant and anti-aging effects of human dermal fibroblasts induced by UV-A [14,15].

As such, it has been reported that cycloheterophyllin is effective in various diseases, but there is no research on the effects of melanin production by cycloheterophyllin. In this study, I examined the effects of cycloheterophyllin on the expression of markers TYRP1, $T Y R P 2, T Y R$, and MITF in B16F10 cells, a melanoma cell line derived from mice, related to the melanin production mechanism.

\section{Results and Discussion}

CCK-8 assay was performed to determine the cytotoxicity of cycloheterophyllin in the $\mathrm{B} 16 \mathrm{~F} 10$ cell line. Various concentrations of cycloheterophyllin were added to measure the cell viability (Figure 1). When treated with a concentration of $20 \mu \mathrm{g} / \mathrm{mL}$ or more, it was confirmed that the survival rate of B16F10 cells significantly decreased compared to the control group. When cycloheterophyllin was added with a concentration of $10 \mu \mathrm{g} / \mathrm{mL}$, the survival rate of B16F10 cells was similar to that of the control group. Hence cycloheterophyllin was added at concentrations of 10,1 , and $0.1 \mu \mathrm{g} / \mathrm{mL}$ in additional experiments.

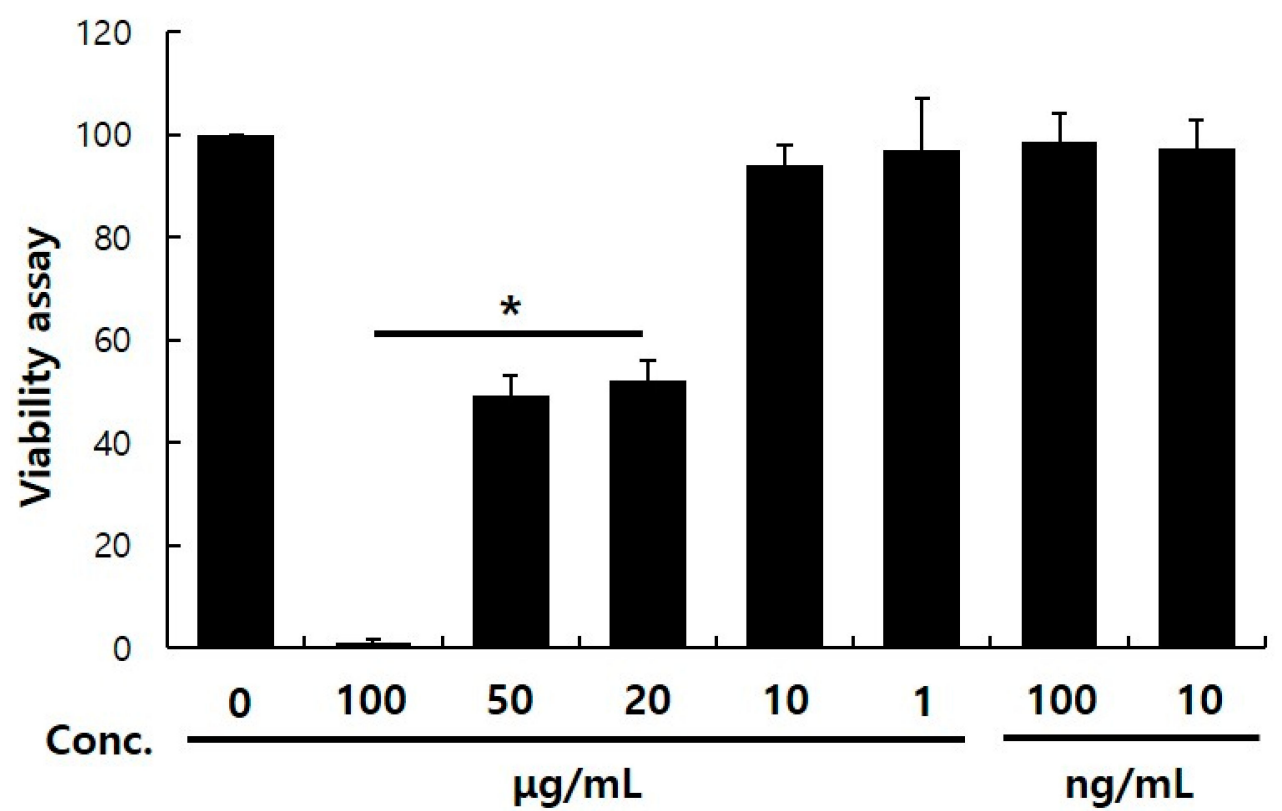

Figure 1. Cytotoxicity aspects of cycloheterophyllin on B16F10 cell line. B16F10 cells were seeded $\left(2 \times 10^{4}\right.$ cells $)$ in 96-well plate and treated with the indicated concentration of cycloheterophyllin for $24 \mathrm{~h}$. Cell viability was measured by CCK- 8 assay. Results are presented as the mean \pm S.D. of the percentage of control optical density in triplicates. ${ }^{*} p<0.05$ compared to control.

Tyrosinase enzyme reacts with L-tyrosine to produce L-DOPA, and L-DOPA finally produces melanin pigment through DOPAquinone by tyrosinase, which is known as a key enzyme that regulates melanogenesis [4,5]. In this experiment, kojic acid was used as a positive control to evaluate the degree of inhibition of tyrosinase enzyme activity. The degree of inhibition of tyrosinase enzyme activity was confirmed by the treatment with cycloheterophyllin at concentrations of 10,1 , and $0.1 \mu \mathrm{g} / \mathrm{mL}$. It was confirmed that tyrosinase enzyme activity was inhibited in a concentration-dependent manner by cycloheterophyllin (Figure 2). In the cycloheterophyllin-treated groups at concentrations of 10,1 , and $0.1 \mu \mathrm{g} / \mathrm{mL}$, it was confirmed that the inhibitory effects of tyrosinase enzyme were $58.0,27.4$, and $16.9 \%$, respectively. 


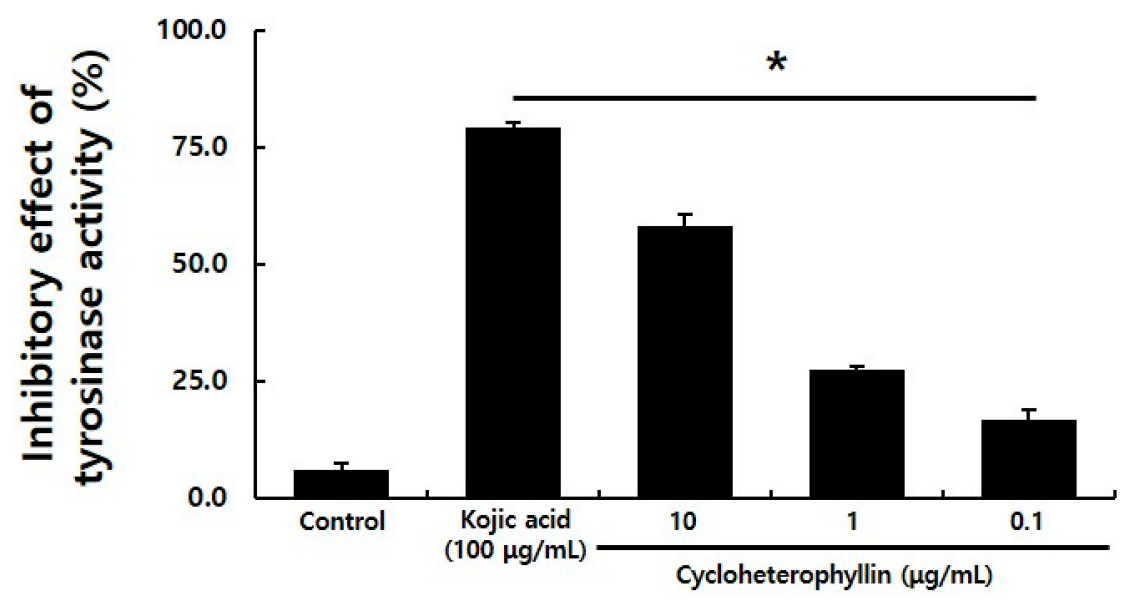

Figure 2. Tyrosinase activity inhibition effect of cycloheterophyllin. Results are the average of triplicate samples. ${ }^{*} p<0.05$ compared with the control.

UV rays stimulate keratinocytes in the epidermis to induce the expression of $\alpha$ melanocyte-stimulating hormone ( $\alpha$-MSH), a hormone that stimulates melanocytes, and is secreted in outside the cell, and the secreted $\alpha$-MSH stimulates melanocytes. By binding to melanocortin 1 receptor (MC1R), it induces signaling related to melanin synthesis in the cell, causing the production of melanin pigment [5]. In this experiment, in order to induce melanin production in B16F10 cells, $200 \mathrm{nM} \alpha$-MSH was used to induce melanin production in B16F10 cells [16]. Real-time RT-PCR of the expression levels of TYRP1, $T Y R P 2, T Y R$, and MITF genes, which are markers that are increased by $\alpha-\mathrm{MSH}$ treatment was determined, by cycloheterophyllin treatment in $\alpha$-MSH-treated B16F10 cells. B16F10 cells were treated with cycloheterophyllin and the expression of the marker was confirmed through real-time RT-PCR. As a result, it was confirmed that the expressions of TYRP1, $T Y R P 2, T Y R$, and MITF were significantly reduced in the cycloheterophyllin-treated group compared to the $\alpha-\mathrm{MSH}$-treated group. Specifically, in the experimental group treated with $10 \mu \mathrm{g} / \mathrm{mL}$ of cycloheterophyllin, the expression of TYRP1, TYRP2, TYR, and MITF genes decreased by 53.3, 26.6, 58, and $34 \%$, respectively (Figure 3). In the experimental group treated with $1 \mu \mathrm{g} / \mathrm{mL}$ cycloheterophyllin, it was confirmed that the expression of the markers was significantly reduced, and the expression of TYRP1 and TYRP2 genes was similarly decreased in the $0.1 \mu \mathrm{g} / \mathrm{mL}$ cycloheterophyllin-treated group.

After confirming that the treatment of cycloheterophyllin reduced the mRNA expression level of a marker related to melanogenesis, the rate of melanin pigment production was confirmed to determine whether the production of melanin pigment in B16F10 cells was substantially reduced (Figure 4). B16F10 cell lines treated with cycloheterophyllin at concentrations of 10,1 , and $0.1 \mu \mathrm{g} / \mathrm{mL}$, respectively, were harvested and the degree of melanin production was confirmed. As a result, it was confirmed that the production of melanin pigment was significantly reduced by cycloheterophyllin at concentrations of 10 and $1 \mu \mathrm{g} / \mathrm{mL}$ (Figure 4A). Additionally, it was confirmed that the production of melanin pigment in the cycloheterophyllin-treated condition was decreased compared to the control group (Figure 4B). When 10 and $1 \mu \mathrm{g} / \mathrm{mL}$ cycloheterophyllin was added, the production rate of melanin pigment decreased by 44.6 and $37.8 \%$, respectively, which was significantly reduced compared to the control group (Figure 4B). These results have a tendency to be consistent with the experimental results of real-time RT-PCR on the mRNA expression levels of melanogenesis-associated marker. 

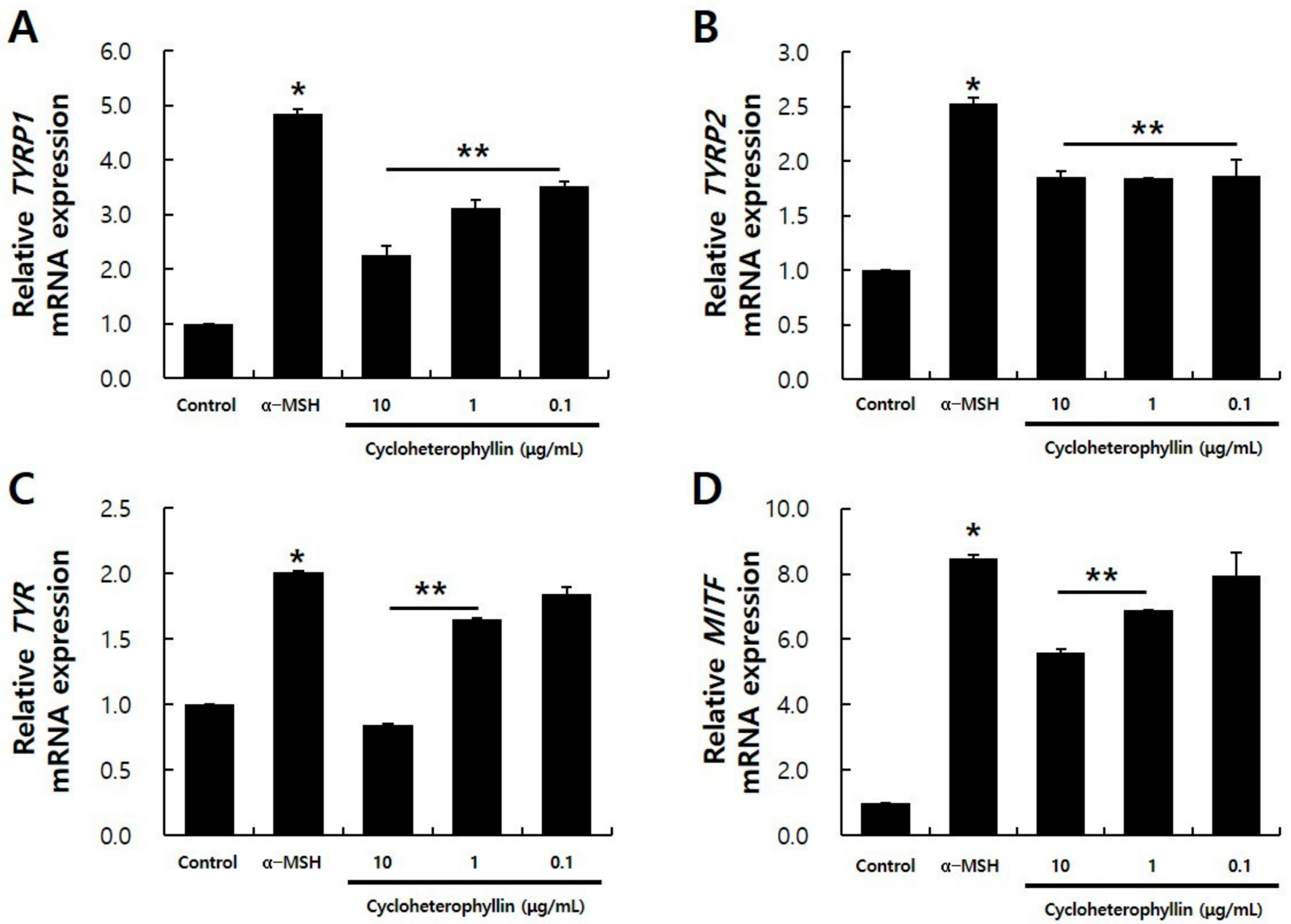

Figure 3. Characterization of cycloheterophyllin treatment on $\alpha$-MSH-treated B16F10 cells. Real-time RT-PCR analysis of melanocyte markers TYRP1 (A), TYRP2 (B), TYR (C), and MITF (D). Values are mean \pm S.D. of three independent experiments. * significantly different compared to control, $p<0.05^{* *}$ significantly different compared to $\alpha$-MSH-treated condition, $p<0.05$.

Antioxidants such as ascorbic acid are known to be an important whitening material that inhibits the synthesis of melanin pigments by reducing DOPAquinone, an intermediate substance during the eumelanin production process, to L-DOPA $[16,17]$. Cycloheterophyllin has also been reported to have antioxidant effects [11,12]. It is shown that cycloheterophyllin may be effective in whitening by this antioxidant effect. As a result of confirming the antioxidant effect in vitro through this DPPH radical scavenging assay, it was confirmed that it has an antioxidant effect comparable to that of ascorbic acid, a positive control under high concentration of cycloheterophyllin (Figure 5). In the future, further research on the antioxidative effects of cycloheterophyllin in melanocytes and the expression of antioxidative enzymes such as catalase, SOD1, SOD2, and SOD3 should be conducted. 


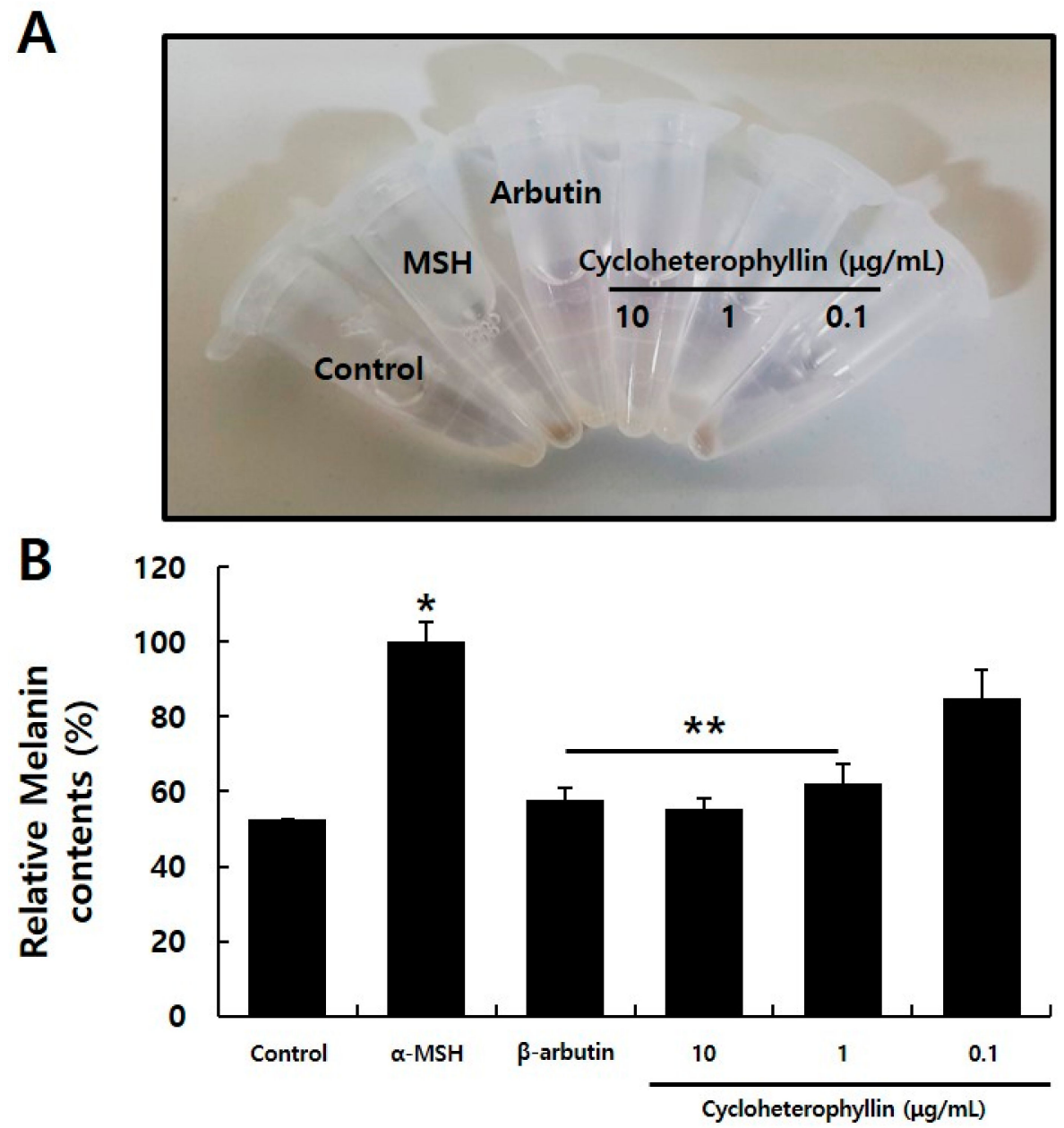

Figure 4. Melanin synthesis inhibition of cycloheterophyllin on B16F10 cells. Representative image of B16F10 cells after cycloheterophyllin treatment (A). Treated cells were lysed with $1 \mathrm{~N} \mathrm{NaOH}$ and absorbance was measured at $405 \mathrm{~nm}$ (B). Results are expressed as means \pm S.D. of three independent experiments. ${ }^{*}$ compared to control, $p<0.05$. ${ }^{* *}$ compared to $\alpha$-MSH-treated condition, $p<0.05$.

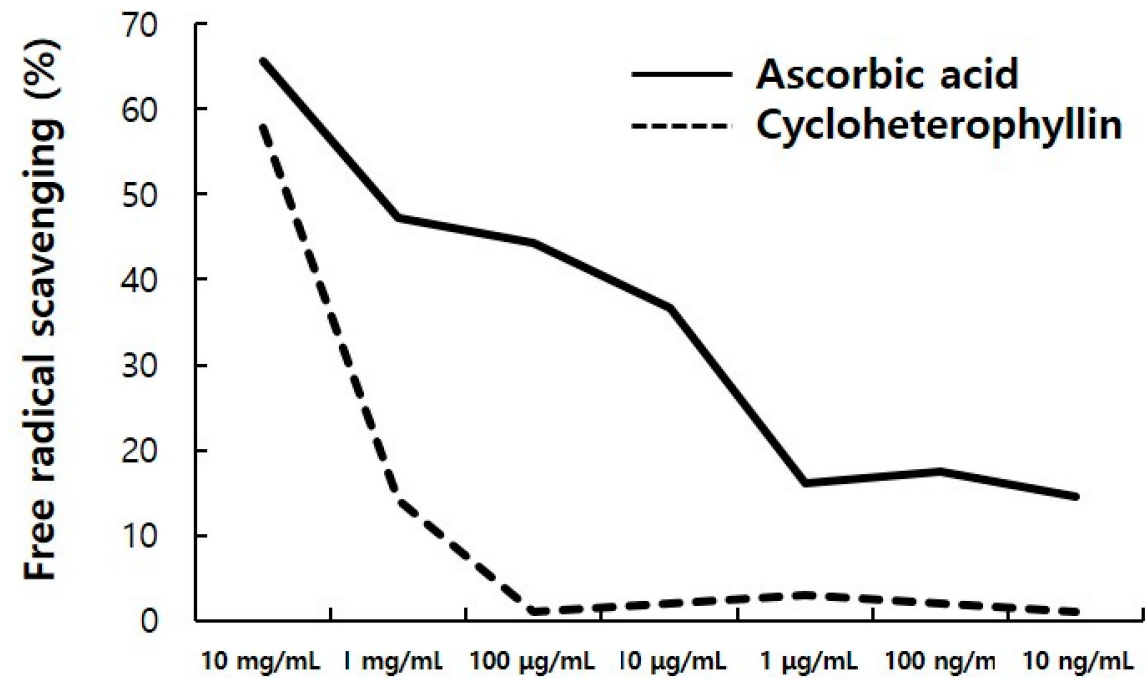

Figure 5. Free radical scavenging of cycloheterophyllin by the DPPH assay. The cycloheterophyllin has an antioxidant ability similar to ascorbic acid, positive control in high concentration of cycloheterophyllin. 


\section{Materials and Methods}

\subsection{Experimental Materials and Cell Culture}

B16F10 cell line was purchased from the Korean Cell Line Bank (Korea), and cell culture medium was $10 \%$ fetal bovine serum(FBS, SFBU-0500, Equitech-bio, Kerrville, TX, USA) in Dulbecco's modified Eagle's medium (DMEM, LM 001-05, Welgene, Gyeongsan-si, Korea), and 1\% penicillin/streptomycin (Gibco, 15140-122, Waltham, MA, USA) was added. Cells were cultured in an incubator at $37^{\circ} \mathrm{C}$ and $5 \% \mathrm{CO}_{2}$ [16]. The cycloheterophyllin used in this experiment was extracted from Artocarpus heterophyllus using DMSO, and purchased from ChemFaces Co. (CFN97748, Wuhan, China, Purity $\geq 98 \%$ ).

\subsection{Cell Viability Assay}

Cell viability was evaluated by CCK-8 solution (Cell counting kit; EZ-3000, EZCytox, Seoul, DoGen). B16F10 cell lines were seeded at culture medium at a density $2 \times 10^{4}$ cells/96 well plate. After 24 h cycloheterophyllin (CFN97748, Chemfaces) was added. B16F10 cell line treated with cycloheterophyllin were incubated for $24 \mathrm{~h}$ and CCK-8 solution was added for $30 \mathrm{~min}$ in a $37^{\circ} \mathrm{C}$ incubator. Absorbance was measured at $450 \mathrm{~nm}$ using a microplate reader (Epoch, Winooski, VT, USA, BioTek) and cell viability was calculated based on the absorbance of the control group without cells [16].

\subsection{DPPH Assay}

For DPPH radical (Sigma-Aldrich, 382051, Darmstadt, Germany) scavenging assay, DPPH was dissolved in methanol:water (3:2) at $0.1 \mathrm{mM}$ concentration. Diluted cycloheterophyllin (50 $\mu \mathrm{L}, \mathrm{CFN} 97748$, Chemfaces) was added to DPPH solution (500 uL) and allowed to react at room temperature for $20 \mathrm{~min}$, followed by a microplate spectrophotometer (Epoch, Winooski, VT, USA, BioTek,) and the absorbance was measured at a $517 \mathrm{~nm}$ wavelength. Ascorbic acid (1043003, Munich, Germany, Sigma-Aldrich) was used as a positive control.

\subsection{In Vitro Mushroom Tyrosinase Activity}

Mushroom tyrosinase (EC 1.14.18.1, Sigma-Aldrich) was dissolved in 1/15 M PBS (pH 6.8) to a concentration of 276 units $/ \mathrm{mL}$ and used. About $150 \mu \mathrm{L}$ of Mushroom Tyrosinase (13.8 units $/ \mathrm{mL}$ ) was reacted with L-tyrosine (T-3754, Sigma-Aldrich) and cycloheterophyllin $(10,1,0.1 \mathrm{ug} / \mathrm{mL})$ for $5 \mathrm{~min}$, and the absorbance was measured at a wavelength of $475 \mathrm{~nm}$. Each experimental group was independently tested three times, and the tyrosinase enzyme inhibition rate (\%) of the material was calculated by applying the following calculation formula. As a positive control, kojic acid (K3125, Sigma-Aldrich) at a concentration of $100 \mu \mathrm{g} / \mathrm{mL}$ was used.

Tyrosinase inhibition ratio $(\%)=(1-$ absorbance of treatment/absorbance of nontreatment) $\times 100$

\subsection{Quantitative Real-Time Reverse Transcription-Polymerase Chain Reaction (Q-RT-PCR)}

Total RNA was isolated using Trizol (15596018, Carlsbad, CA, USA, Thermo Fisher Scientific). The concentration of RNA was determined spectrophotometrically (BioTek). Four micrograms of RNA was reverse-transcribed into cDNA using ReverTra Ace ${ }^{\circledR}$ reverse transcription kit (Toyobo, FSQ101, Osaka, Japan). The reverse transcription was stopped by adding Tris-EDTA buffer ( $\mathrm{pH} 8.0$ ) to a total of $200 \mu \mathrm{L}$ of cDNA solution. The TaqMan ${ }^{\circledR}$ Gene Expression Assay sets were purchased from Applied Biosystems. Q-RT-PCRs were done according to the manufacturer's instructions. Briefly, $20 \mu \mathrm{L}$ of Q-PCR mixture contained $10 \mu \mathrm{L} 2 \times$ TaqMan Universal Master Mix (Applied Biosystems, Foster City, CA, USA), $1 \mu \mathrm{L}$ $20 \times$ Taqman expression assay (Applied Biosystems), and $50 \mathrm{ng}$ cDNA. Q-PCR mixture was reacted in $95^{\circ} \mathrm{C}$ for $20 \mathrm{~s}$ and 40 times cycling reaction $\left(95^{\circ} \mathrm{C}\right.$ for $1 \mathrm{~s}$ and $60^{\circ} \mathrm{C}$ for $20 \mathrm{~s}$ ) with a StepOnePlus System (Applied Biosystems). The gene identification numbers for the TaqMan expression assay used in the Q-RT-PCR analyses are presented in Table 1. Human 
GAPDH (Applied Biosystems) was used for normalizing variation in cDNA quantities from different samples.

Table 1. Gene name and assay ID number in real-time RT-PCR analysis.

\begin{tabular}{ccc}
\hline Symbol & Gene Name & Assay ID \\
\hline TYRP1 & Tyrosinase-related protein 1 & Mm00453201_m1 \\
TYRP2 & Tyrosinase-related protein 2 & Mm01225584_m1 \\
TYR & Tyrosinase & Mm00495817_m1 \\
MITF & Microphthalmia-associated transcription factor & Mm00434954_m1 \\
GAPDH & Glyceraldehyde-3-phosphate dehydrogenase & Mm99999915_g1 \\
\hline
\end{tabular}

\subsection{Melanin Contest Assay}

To measure the amount of melanin pigment, Hosoi's method was partially modified [17]. Total of $1 \times 10^{5} \mathrm{~B} 16 \mathrm{~F} 10$ cells were inoculated into a $60 \mathrm{~mm}$ tissue culture dish. After culturing the cells for $24 \mathrm{~h}, 200 \mathrm{nM}$ of $\alpha$-melancyte stimulating hormone ( $\alpha$-MSH; M4135, Sigma-Aldrich) and cycloheterophyllin (10, 1, $0.1 \mu \mathrm{g} / \mathrm{mL}$ ) were added for $72 \mathrm{~h}$ at each concentration. After removing the culture medium, $200 \mu \mathrm{L}$ of $\mathrm{NaOH}(1 \mathrm{~N} ; \mathrm{S} 8045$, Sigma-Aldrich) solution was added and incubated at $60^{\circ} \mathrm{C}$ for $2 \mathrm{~h}$ to dissolve melanin. The absorbance was measured with a spectrophotometer ( $405 \mathrm{~nm}$, Epoch). As a positive control, $100 \mu \mathrm{g} / \mathrm{mL}$ arbutin (A4256, Sigma-Aldrich) was used. Inhibition of the production of melanin pigment was expressed as a percentage of the amount of melanin produced under the $\alpha$-MSH treatment conditions. It was performed by independently performing three independent experiments.

\subsection{Statistical Analysis}

Statistical analyses were carried out by the one-way analysis of variance (ANOVA). Results are expressed as the means \pm standard deviation of at least three independent experiments.

\section{Conclusions}

UV encountered in daily life have beneficial functions such as vitamin D synthesis and sterilization, but in other aspects, it causes loss of skin elasticity, wrinkles, pigmentation, erythema, inflammation, etc., by a chain reaction of reactive oxygen species $[18,19]$. In addition, exogenous aging caused by external factors such as UV prevents the function of normal tissues and regeneration when the tissue is damaged due to the reduction and deterioration of the constituent cells in the living body [20,21].

Through this study, it was possible to confirm the appropriate concentration of cycloheterophyllin to treat the B16F10 cells. It was confirmed that the concentration of $10 \mu \mathrm{g} / \mathrm{mL}$ did not affect the viability of cells, as shown in Figure 1. By the measurement results of the activity inhibitory effect of the tyrosinase enzyme, it was confirmed that cycloheterophyllin concentrations of 10,1 , and $0.1 \mu \mathrm{g} / \mathrm{mL}$ significantly reduced the activity of the tyrosinase enzyme (Figure 2). In addition, it was confirmed that cycloheterophyllin significantly reduced the expression of markers (TYRP1, TYRP2, TYR, and MITF gene) compared to $\alpha-\mathrm{MSH}$ treated condition (Figure 3). Additionally, it was confirmed that cycloheterophyllin reduced the amount of melanin synthesis in B16F10 cells (Figure 4). Based on these results, cycloheterophyllin shows the potential as a new whitening candidate.

This study is the first to confirm the inhibitory effect of cycloheterophyllin on melanin synthesis, and suggests the possibility of inhibiting skin aging caused by UV rays. In addition, further in-depth its effects on the signaling mechanisms of B16F10 cells, on the signaling systems involved in whitening, and on various antioxidant enzymes present in melanocytes seem to be necessary. 
Funding: This paper was supported by the Semyung University Research Grant of 2021.

Institutional Review Board Statement: Not applicable.

Informed Consent Statement: Not applicable.

Data Availability Statement: The data presented in this study are available in article.

Conflicts of Interest: The author declares no known competing financial interests or personal rela.

Sample Availability: Samples of the compounds are not available from the author.

\section{References}

1. Bonaventure, J.; Domingues, M.J.; Larue, L. Cellular and molecular mechanisms controlling the migration of melanocytes and melanoma cells. Pigment Cell Melanoma Res. 2013, 26, 316-325. [CrossRef] [PubMed]

2. Gilchrest, B.A.; Eller, M.S. DNA photodamage stimulates melanogenesis and other photoprotective responses. J. Investig. Dermatol. Symp. Proc. 1999, 4, 35-40. [CrossRef] [PubMed]

3. Sugumaran, M. Comparative biochemistry of eumelanogenesis and the protective roles of phenoloxidase and melanin in insects. Pigment Cell Res. 2002, 15, 2-9. [CrossRef] [PubMed]

4. Ito, S.; Wakamatsu, K. Quantitative analysis of eumelanin and pheomelanin in humans, mice, and other animals: A comparative review. Pigment Cell Res. 2003, 16, 523-531. [CrossRef]

5. Yoon, Y.M.; Bae, S.H.; An, S.K.; Choe, Y.B.; Ahn, K.J.; An, I.S. Effects of Ultraviolet Radiation on the Skin and Skin Cell Signaling Pathways. Kor. J. Aesthet. Cosmetol. 2013, 11, 417-426.

6. Baek, Y.S.; Ryu, Y.B.; Curtis-Long, M.J.; Ha, T.J.; Rengasamy, R.; Yang, M.S.; Park, K.H. Tyrosinase inhibitory effects of 1,3diphenylpropanes from Broussonetia kazinoki. Bioorg. Med. Chem. 2009, 17, 35-41. [CrossRef]

7. Kim, H.J.; Seo, S.H.; Lee, B.G.; Lee, Y.S. Identification of tyrosinase inhibitors from Glycyrrhiza uralensis. Planta Med. 2005, 71, 785-787. [CrossRef]

8. Han, N.K.; Park, C.M.; Kwon, J.C.; Joung, M.S.; Choi, J.W. Whitening effect of Fagopyrum tataricum extract. J. Soc. Cosmet. Sci. Korea 2014, 40, 179-186.

9. Kim, B.Y.; Park, S.H.; Park, B.J.; Kim, J.J. Whitening effect of Androsace umbellate extract. J. Soc. Cosmet. Sci. Korea 2015, 41, 21-26.

10. Lin, C.N.; Lu, C.M.; Lin, H.C.; Fang, S.C.; Shieh, B.J.; Hsu, M.F. Novel antiplatelet constituents from formosan moraceous plants. J. Nat. Prod. 1996, 59, 834-838. [CrossRef]

11. Wang, J.P.; Raung, S.L.; Tsao, L.T.; Hsu, M.F.; Lin, C.N. Blockade of protein kinase C is involved in the inhibition by cycloheterophyllin of neutrophil superoxide anion generation. Naunyn. Schmiedeberg Arch. Pharm. 1997, 355, 551-558. [CrossRef]

12. Ko, F.N.; Cheng, Z.J.; Lin, C.N.; Teng, C.M. Scavenger and antioxidant properties of prenylflavones isolated from Artocarpus heterophyllus. Free Radic. Biol. Med. 1998, 25, 160-168. [CrossRef]

13. Jantan, I.; Yasin, Y.H.; Jamil, S.; Sirat, H.; Basar, N. Effect of prenylated flavonoids and chalcones isolated from Artocarpus species on platelet aggregation in human whole blood. J. Nat. Med. 2010, 64, 365-369. [CrossRef]

14. Huang, C.H.; Li, H.J.; Wu, N.L.; Hsiao, C.Y.; Lin, C.N.; Chang, H.H.; Hung, C.F. Photoprotective Effects of Cycloheterophyllin against UVA-Induced Damage and Oxidative Stress in Human Dermal Fibroblasts. PLoS ONE 2016, 11, e0161767. [CrossRef]

15. Shim, J.H. Anti-aging effects of cycloheterophyllin in UVA-irradiated dermal fibroblasts. Kor. J. Pharmacogn. 2019, 50, 285-290.

16. Tomita, Y.; Seiji, M. Inactivation mechanism of tyrosinase in mouse melanoma. J. Dermatol. 1977, 4, 245-249. [CrossRef]

17. Panzella, L.; Ebato, A.; Napolitano, A.; Koike, K. The late stages of melanogenesis: Exploring the chemical facets and the application opportunities. Int. J. Mol. Sci. 2018, 19, 1753. [CrossRef]

18. Talwar, H.S.; Griffiths, C.E.; Fisher, G.J.; Hamilton, T.A.; Voorhees, J.J. Reduced type I and type III procollagens in photodamaged adult human skin. J. Invest. Dermatol. 1995, 105, 285-290. [CrossRef]

19. Kim, J.; Lee, C.W.; Kim, E.K.; Lee, S.J.; Park, N.H.; Kim, H.S.; Kim, H.K.; Char, K.; Jang, Y.P.; Kim, J.W. Inhibition effect of Gynura procumbens extract on UV-B-induced matrix-metalloproteinase expression in human dermal fibroblasts. J. Enthnopharmacol. 2011, 137, 427-433. [CrossRef]

20. Kirkwood, T.B. Understanding the odd science of aging. Cell 2005, 120, 437-447. [CrossRef]

21. Jones, D.L.; Rando, T.A. Emerging models and paradigms for stem cell ageing. Nat. Cell Biol. 2011, 13, 506-512. [CrossRef] [PubMed] 